\title{
Structure and Innervation of the Papilla Incisiva (Papilla palatina) of the Shrew, Sorex unguiculatus
}

\author{
TAKESHI YOHRO \\ Department of Anatomy, Faculty of Medicine, University \\ of Tokyo, Hongo, Tokyo 113, Japan \\ -Received for Publication, July 16, 1980-
}

Key words: Papilla incisiva, Papilla palatina, Structure, Innervation, Shrew.

Summary. The structure and innervation of the papilla incisiva (papilla palatina) of the shrew, Sorex unguiculatus were studied by light and electron microscopy. The papillary region of the shrew consists of the papilla proper and two epithelial processes. The main part of the papilla, with the epithelial processes, lies anterior to the incisors and is thus in the vestibulum oris. The papilla is composed of epithelium and lamina propria and has a core of connective tissue. The core contains anastomosing venules, occasional arterioles, fibroblasts and mast cells, and it appears to be a cavernous tissue. The papillary region is densely innervated by nasopalatine nerves, and at least five types of nerve terminals are observable. Terminals with Merkel cells, intra-epithelial free endings and simple encapsulated endings (mammalian end organs) are restricted to the apical part of the papilla proper, and endings like genital corpuscles to its proximal part near the base of the epithelial processes. Nonmyelinated axons and simple bulboid endings are widely distribted in the lamina propria of the papillary region, but axons do not occur in the connective tissue core except for those accompanying blood vessels.

\section{Introduction}

The papilla incisiva (papilla palatina) is a small protubernace located at the most anterior part of the hard palate just posterior to the incisors. The papilla develops from the primary palate (see Peter, 1925); it is innervated by the nasopalatine nerves, which traverse the nasal septum and reach the papilla through the incisive foramen.

The histological structure of embryonic, neonatal and adult human papillae was first detailed by Merkel (1891). He stated that (1) termination of the nasopalatine nerves in the papilla was already known in the 18th century to several anatomists, (2) abundant Merkel cells and nerve endings of genital corpuscular type were observed in the papilla, and (3) the papilla might therefore be a sensery organ. Much later Hochstetter (1936) also stated that the nasopalatine nerves were quite conspicuous in the primary palate of human embryos and that they terminated in the papilla. Recently Hofer (1977) reported the presence of taste buds in the papilla of Nycticebus, a primate. These observations suggest that the papilla is densely innervated and that its pattern of innervation may differ from that of the secondary palate, especially in 
Primates.

The innervation of the palate in general, including the hard palate, has been studied in various animals either by light microscopy (Botezat, 1901, 1907; Kadanoff, 1927 ; Kawahara, 1951 ; Abe, 1954 ; Kamata, 1955 ; Sugimoto, 1956; Nomura, 1957 ; Eto, 1959; Vij and Kanagasuntheram, 1970; Kluger and Schumacher, 1970) or by electron microscopy (Andersen and Nafstad, 1968; Hashimoto, 1972; Hanker, Dixon and Moore, 1973; Akkerman, Bos and Jansen, 1976). However, these observers ignored Merkel's paper, and the innervation of the papilla has received little attention since his day, though some studies have been recorded of the innervation of the nasopalatine duct of the cattle (Sugimoto, 1956), the dog (Kadowaki, 1959) and the whale (Quay and Mitchell, 1971).

In the present study the structure and innervation of the papilla incisiva of the shrew (Sorex unguiculatus) have been examined. The results confirm Merkel's original observations on the human papilla in certain main features. One interesting finding, peculiar to the shrew, is that the main part of the papilla is located anterior to the incisors and thus exterior to the palate.

\section{Materials and Methods}

The animals were collected in Hokkaido, Japan, in July during the years 19751978. They were perfused with $2 \%$ glutaraldehyde in $0.1 \mathrm{M}$ phosphate buffer through the left ventricle of the heart under ether anaesthesia. For electron microscopy block of tissue taken anterior to the incisors were immersed in the aldehyde fixative for 2 hours, and then in $2 \% \mathrm{OsO}_{4}$ in the phosphate buffer for a similar period. They were usually stained en bloc with uranyl acetate, dehydrated in ethanol and embedded in
Araldite.

For light microscopy heads were taken from the perfused animals and preserved in $10 \%$ formalin. The heads were then decalcified, dehydrated in ethanol and embedded in celloidin. Serial sections were cut at 10 or $25 \mu \mathrm{m}$ in thickness and stained with hematoxylin and eosin.

\section{Results}

1. General structure of the papilla incisiva The main part of the papilla was located immediately anterior to the upper incisors. It could easily be demonstrated macroscopically on the ventral aspect of the snout before fixation (Fig. 1). It was small, rhomboid process, elongated and pointed anteriorly but short and less prominent posteriorly; the widest part of the rhomboid was thus more posterior.

Serial frontal sections of the snout allowed more detailed observation of the shape and structure of the papilla (Figs. 2-8). It consisted of a papillary part proper and two epithelial processes, more anterior in position (Fig. 6-8). However. the bases of these processes were, in the more posterior sections, epithelial thickening flanking the papilla proper (Fig. 5). The epithelium belonging to these processes could be distinguished from the surrounding epithelium by its thickness and the lack of epithelial papillae projecting into the lamina propria. The anterior summit of the rhomboid, i.e. that of the papilla proper, showed as a pointed apex (Fig. 6) while the posterior summit, extending toward the palate through the diastema between the incisors as a small ridge, ended just anterior to the incisive canals and Jacobson's organ (Figs. 3. 4) The two grooves, one on each side of the papilla (sulci papillae palatinae of Hofer, 1977), were continuous with the nasopalatine ducts into which Jacobson's organ opened (Fig. 3). 
The papilla proper consisted of epithelial and connective tissue (Figs. 5, 6, 9). In the latter there was "core" (Bindegewebskern, Merkel, 1891) which occupied the main volume of connective tissue, especially at the posterior part of the rhomboid papilla (Figs. 5, 9). This core was a cylindrical body which tapered anteriorly as well as posteriorly; it is almost completely round in cross sections through its middle region, but flattened dorsoventrally near its two opposite ends. The histological structure of the core was characterized by an abundance of anastomosing venules (Fig. 9). The interstitium of the core was more lightly stained than that of the surrounding connective tissue, suggesting the relative scarcity of connective tissue elements in the core.

The left and the right nasopalatine nerves (branches of pterygopalatine ganglia), each contained more than 200 myelinated nerve fibres, traversed the nasal septum to pass through the very narrow space between Jacobson's organs of the two sides. Here the two nerves were situated one above the other (Fig. 2). Immediately after entering the papilla the nerves divided into several smaller bundles, which were deep to the connective tissue core. The terminal branches were distributed to the epithelium and lamina propria between the epithelium and the core of the papilla.

\section{Innervation of the papilla}

At least five types of terminals were observed within the papilla by electron microscopy. These were 1) terminals with Merkel cells, 2) intra-epithelial free endings, 3) mammalian end organs, 4) endings like genital corpuscles and 5) nonmyelinated axons of variable diameter. The first two were in the epithelium and the others in the lamina propria.

Merkel cells, intra-epithelial free endings and mammalian endorgans were restricted to the anterior apical part of the papilla incisiva. Here the papilla had a sharp edge ventrally (Fig. 6), and from the epithelium many thin and elongated epithelial papillae extended into lamina propria (Figs. 6, 10). Each epithelial papilla contained one to three Merkel cells with nerve terminals (Fig. 10), and usually Merkel cells were arranged in a column in each epithelial papilla. In sections across the papilla usually one Merkel cell lay in the centre, surrounded by epithelial cells and not directly contiguous with the basement membrane. The epithelial papilla was like the 'Merkel rete papilla' described in the paw skin of racoons (Munger, Pubols and Pubols, 1971), though each papilla in the shrew was so thin that its cross sectional profiles often consisted of only a few cells including one central Merkel cell. The free endings were observed in the epithelium overlying the epithelial papillae. They contained agranular vesicles of various sizes, granular vesicles, and often some mitochondria (Fig. 11). Mammalian endorgans were located in the subepithelial regions of the lamina propria, between or subjacent to the epithelial papillae (Fig. 12). The central axon was encapsuled by several cytoplasmic laminae each of which was surrounded by the basement membrane. The terminology for this type of ending has varied ('mammalian end organ'-Loo and Kanagasuntheram, 1972, 1973 ; 'Krause end buld'-Spassova, 1973; 'simple encapsulated corpuscle with inner core'-Halata, 1975). Endings like genital corpuscles were observed in the proximal part of the papilla incisiva, but they were absent from the apical part of the papilla. They were observed relatively deep in the lamina propria subjacent to the epithelial processes described above (Fig. 9). The axons were loosely surrounded by several cytoplasmic processes with numerous caveolae (Ffg. 13). These 
endings showed features typical of those previously described in mucocutaneous junctions ('genital end bulb,'-Patrizi and Munger, 1965 ; 'mucocutaneous end organ,' -Loo and Kanagasuntheram,1973).

Besides these identifiable types of end organ there were many nonmyelinated axons in the lamina propria. Some of them were terminal parts of thick myelinated axons and probably represented simple bulboid endings (Halata, 1975; 'connective tissue free endings'-Yohro, 1977). Others were thin and more like those described in the rat auricula (Cauna, 1969) or in the human skin (Cauna, 1973). Only these thin nonmyelinated axons were distributed throughout the superficial layers of the lamina propria of the paplla incisiva.

\section{Fine structure of the connective tissue core}

The core was composed of blood vessels, fibroblasts, mast cells and connective tissue fibrils (Fig. 9). Near the surface of the core elongated fibroblasts and collagen fibrils formed concentric layers, but cells in the core were irregular in shape and sparse collagen bundles ran in various directions. Venules, the diameter of which was less than $50 \mu \mathrm{m}$, occurred deep in the core and near its surface. They were usually surrounded by a loose, discontinuous layer of nonstriated muscle, and were occasionally accompanied by bundles of nonmyelinated axons. Except for these there were no terminals in the core. Arterioles were present, but arterio-venous anastomoses were not observed.

Many of the fibroblasts of the core contained many $100 \AA$ filaments in their cytoplasm (Fig. 14). They were also surrounded by a layer of fibrils, mostly composed of microfibrils but also of occasional elastic fibers and collagen fibrils (Fig. 14). Mast cells were frequent and often surrounded by a cytoplasmic process, probably derived from adjacent fibroblasts.

\section{Discussion}

The present study supports Merkel's observations on the human papilla and his suggestion that the papilla may have some specialized sensory function (Merkel, 1891). His view is also applicable to the shrew. The apex of the papilla of the shrew must be highly sensitive to external stimuli. This is shown by its dense innervation, the restricted distribution of different types of terminal and the presence of specialized epithelial papillae.

The types of termenal observed in the papilla of the shrew have also been reported in the rhinarium of various mammals (Munger, 1965; Nafstad, 1971, 1972; Halata, 1972a, b; Loo and Kanagasuntheram, 1972, 1973; Spassova, 1973; Macintosh, 1975); and most of these terminals have been regarded as mechanoreceptors (see also Andres and von Düring, 1973; Halata, 1975.) Thus the function of the papilla of the shrew seems to be mainly mechanoreceptor, though the exact role of the papilla in the life of the shrew is as yet unknown.

The structure of the connective tissue core suggests that it is a type of cavernous tissue similar to that in the nasal septum or the concha (Bojsen-Møller and Fahrenkrug, 1971). It contains venules with non-striated muscle and nonmyelinated nerve fibres. Similar venules of larger size have been observed in the cavernous tissue of the human concha (Körner, 1937 ; Temesrékási,1969 ; Cauna and Cauna, 1975). The presence of mast cells also shows that a vascular function is important in the core. When the papilla is cut by a razor blade, the core swells and projects from the cut surface. The occurrence of abundant $100 \AA$ filaments 
in the cytoplasm of fibroblasts, and also of a layer of connective tissue fibrils around these cells, may be due to mechanical stress caused by frequent changes in vascular volume in the papilla and by contact of the papilla with foreign bodies. The association of erectile bodies with mechanoreceptors in genital organs is familiar, and the papilla may be regarded as another example of such an association. Hofer (1977), however, suggested a possible function of the veins and erectile bodies in closing the sulci papillae palatinae and the nasopalatine and vomeronasal ducts.

The structure of papilla incisiva varied much among mammals, though recorded observations are few. The variations occur in macroscopic appearance (Retzius, 1906), in the position of the papilla relative to the incisors, in structural components such as the connective tissue core, epithelial processes and cartilage (cartilago papillae palatinae, Starck, 1967), and also in the types of nervous terminal observed in the papilla. In insectivores the papilla is anterior to the incisors of the shrew, between them in the hedgehog and posterior to them in the mole. Two epithelial processes are observed in the papillary region of the shrew, and in the hedgehog direct observation reveals an elongated process on each side of the papilla proper, extending anteriorly to reach the rhinarium (see also Retzius, 1906). In mole and pig embryos the papillary region consists of three prominences (Inouye, 1912; Peter, 1914). A cartilago papillae palatinae has been described in several mammalian species (Broom, 1902, 1915; Christie-Linde, 1914). Detailed comparative studies are perhaps necessary to constitute a generalized concept of the structure and function of the papilla in mammals.

Hofer (1977) made an interesting suggestion as to the possible functional relation- ship between the rhinarium, papilla incisiva and Jacobson's organ dependent upon their anatomical connexion through the labial cleft and sulcus papillae palatinae. It can also be pointed out that all these structures are derived from the medial nasal prominence. The terminal nerve may also be included, since it is possibly sensory (Bojsen-Møller, 1976). These sensory components of the medial nasal prominence are diverse, in contrast to the vibrissae which are the main sensory component of the maxillary and lateral nasal prominences (Yamakado and Yohro, 1979).

\section{Acknowledgement}

The author is greatly obliged to Prof. R. Warwick, Guy's Hospital Medical School, for his critical reading of the manuscript.

\section{References}

1) Abe, Y.: Fine structure of nasal and oral cavities in dog and their sensory innervation, especially on the intraepithelial fibres. Tohoku J. exp. Med. 60, 115-128, 1954.

2) Akkerman, B., Bos, R., Jansen, H.W.B.: The innervation of the hard palate in the rat. J. Dent. Res. 55, D165, 1976.

3) Andersen, A.E., Nafstad, P.H.J.: An electron microscopic investigation of the sensory organs in the hard palate region of the hen (Gallus domesticus). Z. Zellforsch. 91, 391-401, 1968.

3) Andres, K.H., von Düring, M.: Morphology of cutaneous receptors. In.: Handbook of Sensory Physiology (A. Iggo ed.) Vol. II. Berlin: Springer 1973.

5) Bojsen-Møller, F., Fahrenkrug, J.: Nasal swell-bodies and cyclic changes in the air passage of the rat and rabbit nose. J. Anat. (London) 110, 25-37, 1971.

6) Bojsen-Møller, F.: Demonstration of terminalis, olfactory, trigeminal and peri- 
vascular nerves in the rat nasal septum. J. comp. Neur. 159, 245-256, 1976.

7) Botezat, E.: Die Innervation des harten Gaumens der Saugetiere. Z. wiss. Zool. 69, 429-443, 1901.

8) Botezat, E.: Beitrage zur Kenntnis der Nervenenden in der Mundschlemhaut. Anat. Anz. 31, 575-594, 1907.

9) Broom, R.: On the organ of Jacobson in the elephant shrew (Macroscelides pro. boscideus). Proc. zool. Soc. London 1902, 224-228, 1902.

10) Broom, R.: On the organ of Jacobson and its relatiohs in the Insectivora: Part I. Tupaia and Gymnura. Proc. zool. Soc. London 1915, 157-162, 1915.

11) Cauna, N.: The fine morphology of the sensory receptor organs in the auricula of the rat. J. comp. Neur. 136, 81-98, 1969.

12) Canna, N.: The free penicillate nerve endings of the human hairy skin. J. Anat. 115, 277-288, 1973.

13) Cauna, N., Cauna, D.: The fine structure and innervation of the cushion veins of the human nasal respiratory mucosa. Anat. Rec. 181, 1-16, 1975.

14) Christie-Linde, A.A.: On the cartilago palatina and the organ of Jacobson in some mammals. Morph. Jb. 48, 343-364, 1914.

15) Eto, S.: On the sensory nerve distribution in the mucous membrane of the cavum oris and the pars nasalis pharyngis of cat in last fetal stages. Arch. histol. jap. 17, 569-589, 1959.

16) Halata, $Z$.: Innervation der unbehaarten Nasenhaut des Maulwurfs (Talpa europaea). I. Intraepidermale Nervenendigungen. Z. Zellforsch. 125, 108-120, 1972.

17) Halata, Z.: Innervation der unbehaarten Nasenhaut des Maulwurfs (Talpa europaea). II. Innervation der Dermis (einfache eingekapselte Korperchen). Z. Zellforsch. 125, 121-131, 1972 b.

18) Halata, Z.: The mechanoreceptor of the mammmalian skin. Ultrastructure and morphological classification. Adv. in Anat. Embryol. Cell Biol. Vol. 50/5 Berlin : Springer 1975.
19) Hanker, J.S., Dixon, A.D., Moore, H.G.: Cytochrome oxidase activity of mitochondria in sensory nerve endings of mouse palatal rugae. J. Anat. 116, 93$102,1973$.

20) Hashimoto, K.: Fine structure of Merkel cell in human oral mucosa. J. invest. Derm. 58, 381-387, 1972.

21) Hochstetter, F.: Beitrage zur Entwicklungsgeschichte des menschlichen Gaumens. Morph. Jb. 77, 179-272, 1936.

22) Hofer, H.O.: The anatomical relations of the ductus vomeronasalis and the occurrence of taste buds in the papilla palatina of Nycticebus coucang (Primates, Prosimiae) with remarks on strepsirrhinism. Morph. Jb. 123, 836-856, 1977.

23) Ineuye, M.: Die Entwicklung des sekundären Gaumens einiger Säugetiere. Anat. Hefte 46, 1-184, 1912.

24) Kadanoff, D.: Beitage zur Kenntnis der intraepithelialen Nerven des Menschen. 1. Die Nerven im Epithel der Gaumenschleimhaut. Z. Zellforsch. 5, 615-619, 1927.

25) Kadowaki, S.: On the nerve supply of the nasopalatine duct and the Jacobson's organ of dog in the later fetal stage. Arch. histol. jap. 17, 437-458, 1959.

26) Kamata, S.: On the innervation, especially sensory innervation of mucous membrane of the oral cavity of cat. Arch. histol. jap. 8, 234-260, 1955.

27) Kawahara, G.: Studien uber die Nervenapparate in der Schleimhaut des Menschen. Arch. histol. jap. 3,71-79, 1951.

28) Kluger, S., Schumacher, G.H., Stach, W., Gruber, D.: Zur Innervation der Mundhöhle und des Schlundes. Deutsche Zahn-, Mund-, Kieferheilk. 54, 335-342, 1970.

29) Körner, F.: Über Drosselvenen im Schwellgewebe der Nasenschleimhaut. Z. mikrosk.-anat. Forsch. 41, 131-150, 1937.

30) Loo, S.K., Kanagasuntheram, R.: Innervation and structure of the snout in the tree shrew. J. Anat. (London) 111, 253-261, 1972.

31) Loo, 'S.K., Kanagasuntheram, R.: Innervation of the snout in the slow loris. J. 
Anat. 116, 385-393, 1973.

32) Macintosh, S.R.: Observations on the structure and innervation of the rat snout. J. Anat. 116, 537-546, 1975.

33) Merkel, F.: Die Papilla palatina des Menschen. Anat. Hefte 1, 225-232, 1891.

34) Munger, B.R.: The intraepidermal innervation of the snout skin of the opossum. A light and electron microscope study, with observations on the nature of Merkel's Tastzelle. J. Cell Biol. 26, 79971965.

35) Munger, B.L., Pubols, L.M., , Pubols, B.H.: The Merkel rete papilla-a slowly adapting sensory receptor in mammmalian glabrous skin. Brain Res. 29, 47-61, 1971.

36) Nafstad, P.H.J : On the ultrastructure of neuro-epithelial interactions. The dermal innervation in the snout of the pig. Z. Zellforsch. 122, 528-537, 1971.

37) Nafstad, P.H.J.: On the dermal innervation. Z. Anat. Entwickl.-Gesch. 135, 337-349, 1972.

38) Nomura, H.: Studies on the nerveendings in the mucous membrane of the oral cavity, with special reference to their fine structures. (1) Sensory nerveendings in the palate of the rabbit. J. Osaka City Medical School 6, 278-287, 1959.

39) Peter, K.: Die Entwickelung der Papilla palatina beim Menschen. Anat. Anz. 33-50, 1914.

40) Peter, K.: Die Entwicklung des Säugetiergaumen. Erg. d. Anat. Entg. 25, 448-564, 1925.

41) Quay, W.B., Mitchell, E.D.: Structure and sensory apparatus of oral remnants of the nasopalatine canals in the fin whale (Balaenoptera physalus). J. Morph. 134, 271-280, 1971.

42) Retzius, G.: Die Gaumenleisten des Menschen und der Tiere. Biologische Untersuchungen 13, 117-168, 1906.

43) Spassova, I.: Ultratructure of Krause end-bulbs in the nasal skin of the cat. Acta anat. 84, 224-236, 1973.

44) Starck, D.: Le crane des mammiferes. In: Traité de Zoologie, tome 16, fasc. 1, p472 Paris: Masson 1967.

45) Sugimoto, R.: Histology and innervation of the upper lip, the hard palate and the nasopalatine duct of cattle embryo. Arch. histol. jap. 11, 213-237, 1956.

46) Temesrékási, D.: Mikroskopischer Bau und Funktion des Schwellgewebes der Nasenmuschel des Menschen. Z. mikrosk.anat. Forsch. 80, 219-229, 1969.

47) Vij, S., Kanagasuntheram, R.: Sensory nerve terminations in the oral tissues of tree shrew (Tupaia glis) and gibbon (Hylobates agilis). Arch. oral Biol. 15, 1047-1057, 1970.

48) Yamkado, M., Yohro, T.: Subdivisions of mouse vibrissae on embryological basis with descriptions of variations in the number and arrangement of sinus hairs and cortical barrels in Balb/c (nu/t; nude, $\mathrm{nu} / \mathrm{nu})$ and hairless $(\mathrm{hr} / \mathrm{hr})$ strains. Am. J. Anat. 155, 153-174, 1979.

49) Yohro, T.: Structure of the sinus hair follicle in the big-clawed shrew, Sorex unguiculatus. J. Morph. 153,333-354, 1977. 


\section{Explanation of Figures}

\section{Plate I}

Fig. 1. Ventral aspect of a shrew's head. The long muzzle has been displaced and the labial sulcus has been opened by forceps to show the papilla incisiva (arrow). Note that the papilla is anterior to the upper incisors. The lines on the left indicate the approximate levels of sections shown in Fig. 2 to Fig. 8.

Figs. 2-8. Photomicrographs of serial sections to show the structure of the papillary region. Celloidin-embedded specimen. $\times 30$. The appoximate level of each section is indicated in Fig. 1, and the figures are numbered consecutively from posterior to anterior. E, epithelial process; $\mathrm{i}$, incisor; $\mathrm{L}$, tongue; $\mathrm{N}$, nasal cavity; $\mathrm{P}$, papilla incisiva; $\mathrm{S}$, nasal septum.

Fig. 2. The right and the left nasopalatine nerves (arrow) are situated between Jacobson's organs $\left(^{*}\right)$, and one of the nerves is above and the other below.

Fig. 3. Nasopalatine nerves (arrow) are still between Jacobson's organs, but are situated in the same horizontal plane. The anterior end of Jacobson's organ is shown in this figure.

Fig. 4. Posterior part of the papilla incisiva (P) between the incisors (i). The triangle indicates the connective tissue core. 

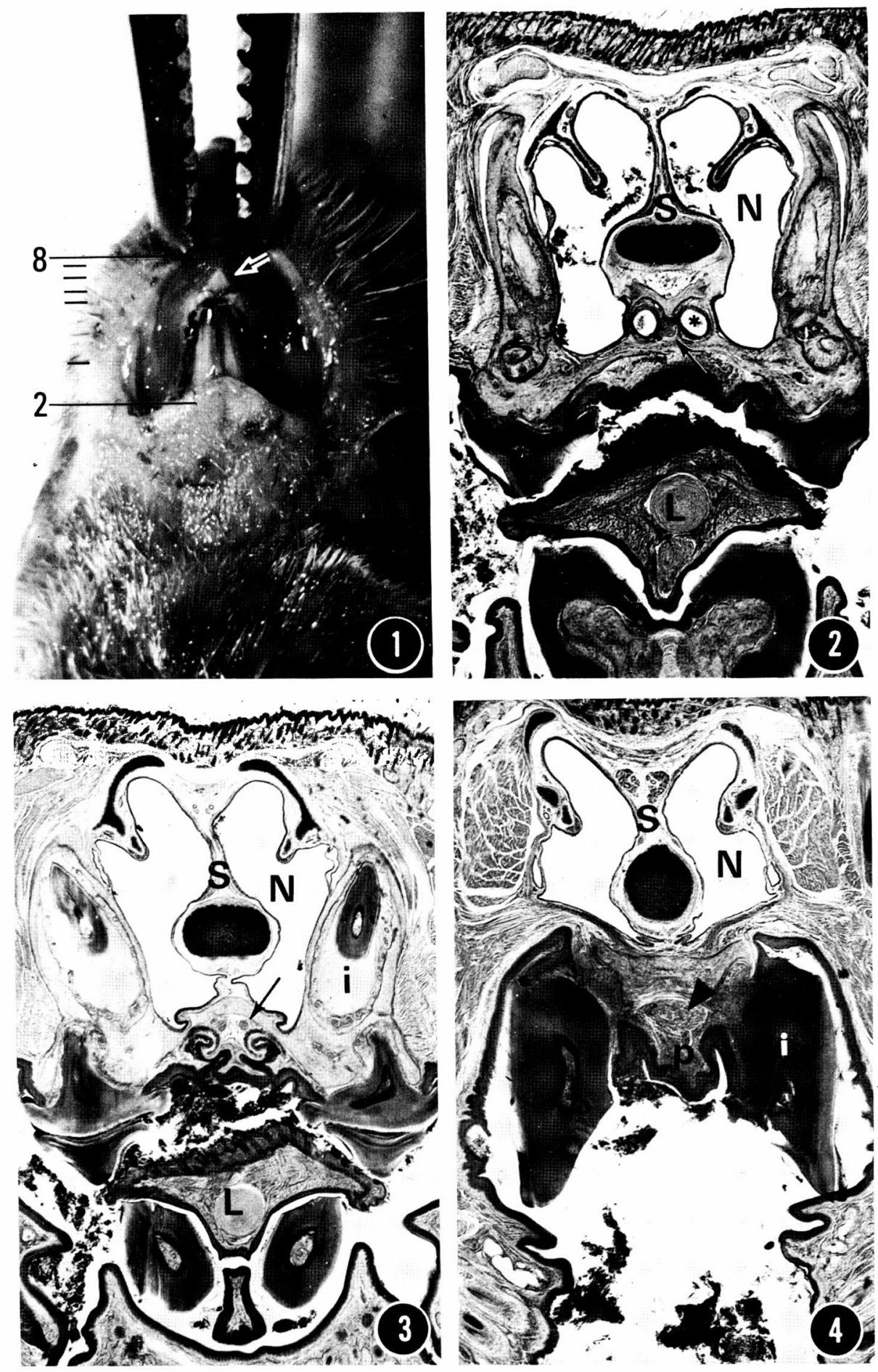


\section{Plate II}

Fig. 5. Widest part of the papilla (P). The epithelial process (E) is still broad and flat. The core is large (triangle).

Fig. 6. Pointed ventral ridge of the papilla $(P)$ is shown. Arrow indicates the retial ridges. The epithelial process (E) and the core (triangle) are indicated.

Fig. 7. The part near the anterior end of the papilla proper. The core (triangle) is still visible between the epithelial processes $(E)$.

Fig. 8. The two epithelial processes (E). The papilla proper and its core are absent.

Fig. 9. Araldite section stained with toluidine blue. $\times 120$. Photomicrograph showing the widest part of the papilla. Note the presence of many venules in the core. Arrows indicate the approximate boundary between the core and the lamina propria. The circle indicates the approximate position of the area shown in Fig. 13. M, striated muscle. 

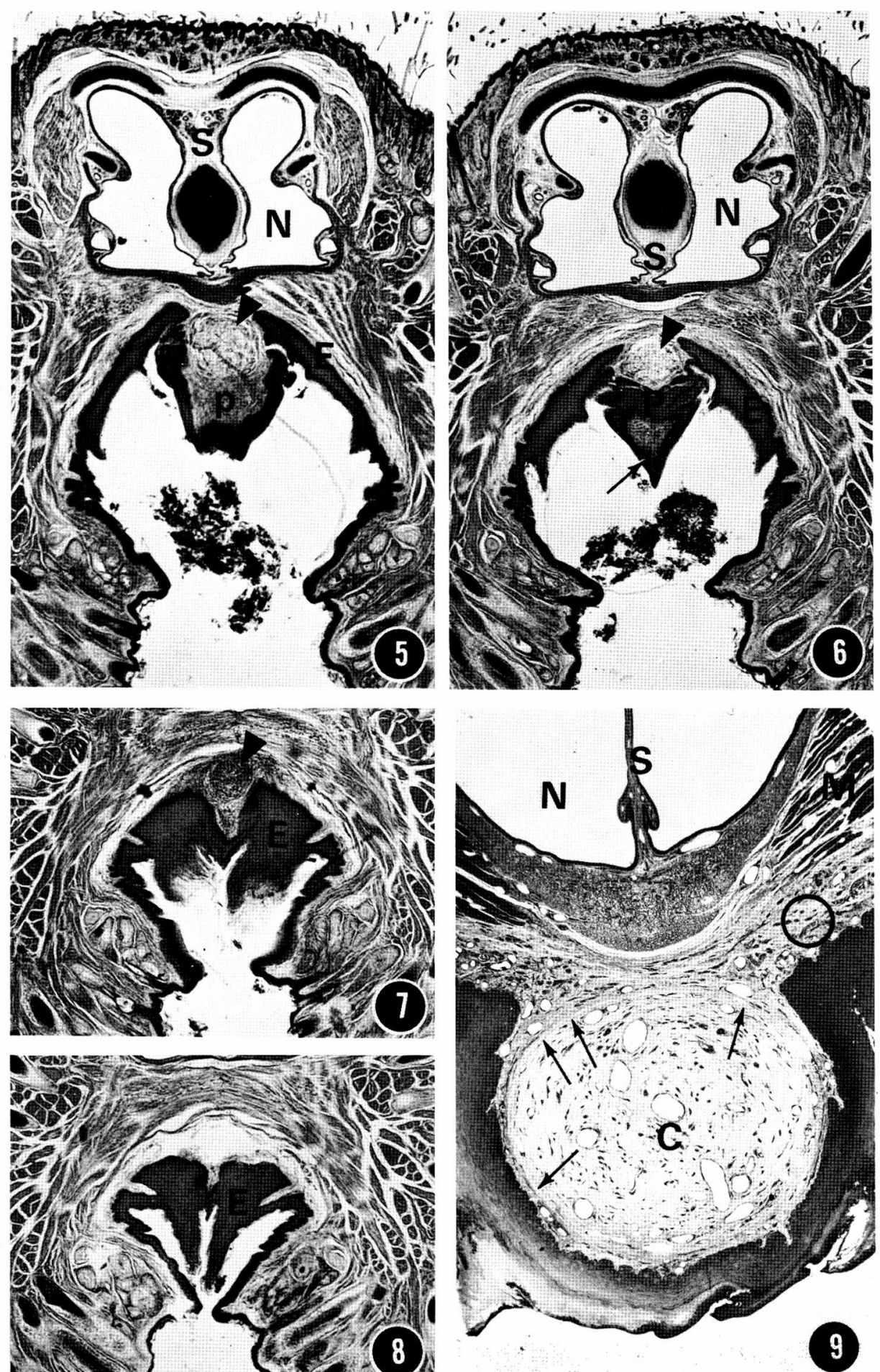


\section{Plate III}

Fig. 10. Low power electron micrograph to show epithelial papilla with a Markel cell (M). Papillae containing two or three Merkel cells are most common. $\times 4,000$.

Fig. 11. An intra-epithelial nerve fibre (A) observed in the epithelium above the retial papilla.

A cytoplasmic process of cell of Langerhans (L) is also seen. Ec, epithelial cell. $\times 15,000$.

Fig. 12. Mammalian endorgan in the apical part of the papilla. Ec, epithelial cell. $\times 11,000$. 


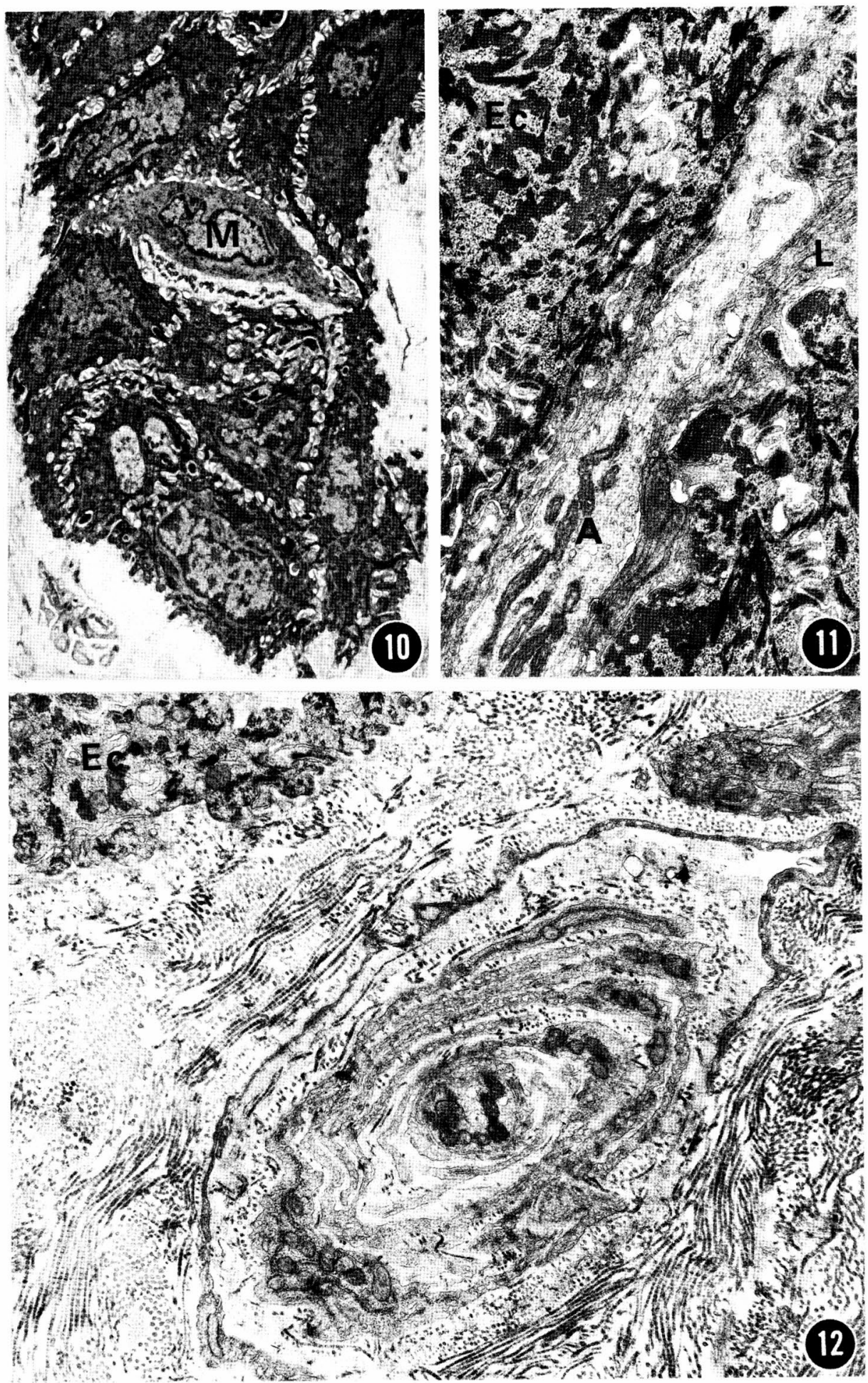




\section{Plate IV}

Fig. 13. An ending of genital corpuscular type observed in the area as shown in Fig. 9 by the circle. A, nerve fibre. $\times 10,000$.

Fig. 14. Fibroblast observed in the core. Arrows indicate $100 \AA$ filaments. Note the layer of connect ve tissue fibrils surrounding the fibroblast. $\times 15,000$. 


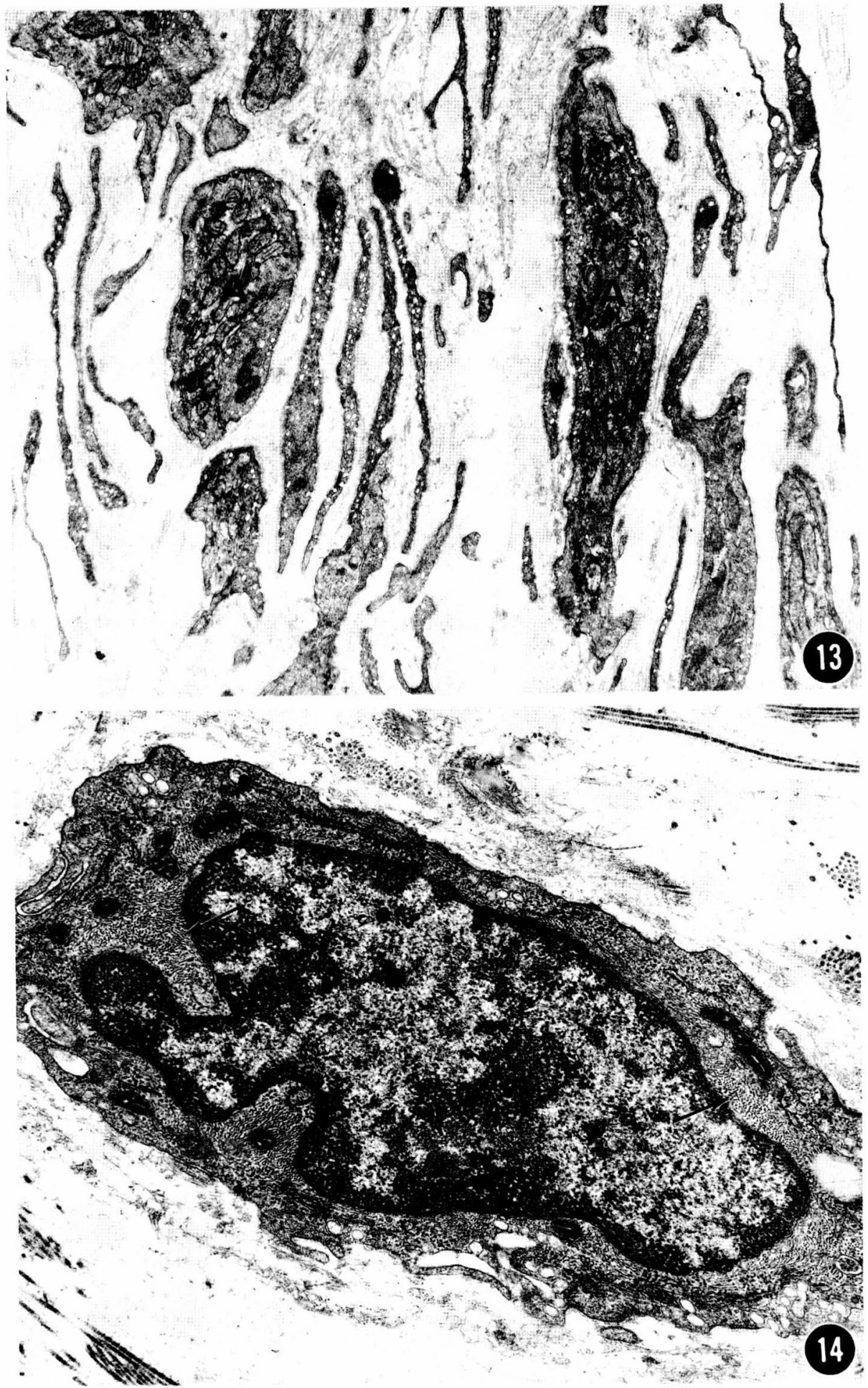

